\title{
Relevance of Net Asset Value (NAV) in Determining the Volatility of Stock Returns: A Study on Dhaka Stock Exchange
}

\author{
Md Saiful Islam ${ }^{1}$, Md Lutfor Rahman ${ }^{2}$ \\ ${ }^{1}$ Department of Business Administration, German University Bangladesh, Gazipur, Bangladesh \\ ${ }^{2}$ Department of Business Administration, Northern University Bangladesh, Dhaka, Bangladesh \\ Email address: \\ bdsaif7811@yahoo.com (Md S. Islam), lut4@yahoo.com (Md L. Rahman)
}

\section{To cite this article:}

Md Saiful Islam, Md Lutfor Rahman. Relevance of Net Asset Value (NAV) in Determining the Volatility of Stock Returns: A Study on Dhaka Stock Exchange. International Journal of Finance and Banking Research. Vol. 2, No. 1, 2016, pp. 7-12. doi: 10.11648/j.ijfbr.20160201.12

\begin{abstract}
This research paper investigates the relevance of NAV per share in influencing the volatility of share prices. Standard deviation has been considered as the measurement scale of volatility. Besides NAV, the other variables considered include P/E ratio, face value and market lot size. Using 92 companies for the period between 2000 to 2009 , this research found NAV per share has significant impact in determining the market volatility. Unlike what happened in the Dhaka Stock Exchange during the years between 2006-2010, changes in the face value and the market lot size should not have any impact in determining the market volatility.
\end{abstract}

Keywords: NAV, Market Lot Size, Share Face Value, Stock Market Volatility, DSE

\section{Introduction}

The stock market in Bangladesh is one of the emerging markets consisting of two markets- Dhaka Stock Exchange and Chittagong Stock Exchange. Dhaka Stock Exchange has started its operation from 1956, and Chittagong in 1994. Though, it has been quite a long time that both the markets started their operations, most of the studies related to their efficiency led to the conclusion that the markets are primarily weak form efficient. (Rahman, et al 2010a, 2010b, Shahiduzzaman, and Naser, 2006, Imam, and Amin, 2003, Chowdhury, 1994). Whenever, the SEC, the governing body of both the stock exchanges, makes/approves a decision regarding company related factors, the share prices and their volumes are affected. One such incidence has been the decision of allowing the changes in the face value per share and the changing of market lot size of many companies during the period from 207 to 2010. It could have been one of the prime reasons for shooting up of the indexes during the period. This event has necessitates that a study should be done to see if there is any correlation between the high market fluctuation in the returns of the individual stocks and the changing of the face value and market lot.

The current study will attempt to identify the most influencing factors responsible for the volatility of these stock markets besides taking into consideration of the face value and market lot size. The other most important variables considered for analysis of this study will include the $\mathrm{P} / \mathrm{E}$ ratio, and the NAV per share of the company.

\section{Literature Review}

There are a diverse number of literatures available on the stock market returns and their volatility. There are literatures which tried to highlight on the factors that may have impact on returns as well as on volatility. Having the view of volatility of returns and their causes the following literature survey has been conducted.

Aggarwal (2003) examined the integration of the three participating equity markets before and after the 1993 passage of NAFTA based on daily, weekly, and monthly data for seven years before and after the passage of NAFTA (1988-2001), unit root tests for the overall period 1988-2001 and the two sub-periods, 1988-1993 (pre-NAFTA) and 19942001 (post-NAFTA), indicate that stock prices are 54 International Research Journal of Finance and Economics Issue 16 (2008) non-stationary but stock returns are generally stationary for all three markets for all three periods. However, daily, weekly, and monthly equity prices in the three NAFTA countries are co-integrated only for the post-NAFTA period.

Naeem (2000) examined the inter-linkages among South 
Asian equity markets and equity markets of United States and United Kingdom for the period 1/94 to 12/99. Monthly stock market indices of Pakistan, India, Sri Lanka, Bangladesh, United States and United Kingdom have been investigated by using vicariate and multivariate co integration analysis. Results reveal that no long term relationship exists among these markets in full sample period. However, in pre-nuclear test period co integration is observed. It is worth mentioning that south Asian markets are not co integrated with equity markets of the United States and United Kingdom.

Mukherjee (2002) finds that Dhaka Stock Exchange (DSE) returns cannot be explained by developed and world markets' returns, implying the segmentation of it from the world. However, the integration between Bangladesh and developed countries increased gradually during the 1990s.

Korajczyk (1996) measured the deviations of asset returns from an equilibrium model assuming market integration. Applying the measure to stock returns from 24 emerging markets indicate that market segmentation tends to be much larger for emerging markets than for developed markets, and the measure tends to decrease over time.

Bekaert and Harvey (1994) used the world portfolio as a benchmark for measuring risk. They reported that an unconditional single-factor CAPM is unable to characterize returns in emerging markets. This phenomenon means that emerging markets are less integrated with world market. However, they observe that the slope coefficient of the country return on the world portfolio return (Beta) has increased for most emerging markets in recent years. They interpreted this as signs of increased integration.

Harvey (1994) tested multi-factor models and finds significant evidence that global risk factors are not powerful in explaining returns in emerging markets, especially compared with explaining returns in industrial countries. His evidence is consistent with the view that the emerging markets are segmented from developed markets.

Buckberg (1995), and Tandon (1994) used a single-factor CAPM in which expected returns are allowed to change over time and fount that emerging equity markets were integrated in the years (1984-1991), whereas the paper has rejected the proposition for many of the countries in the earlier period (1977-1984). The finding suggests that the benefits of further diversifying into emerging markets have been reduced and thought that increase in capital inflows from industrial economies that began in the late 1980s, is the main cause behind recent integration.

Ferson and Harvey (1994) examine multi-factor asset pricing models for eighteen national equity markets. They found that world market betas do not provide a good explanation of cross-sectional differences in average returns. Multiple beta models improve the explanatory power of equity returns.

Harvey (1995a) found that standard global asset pricing models, which assume complete integration of capital markets, fail to explain the cross-section of average returns in emerging countries. An analysis of the predictability of the returns reveals that emerging market returns are more likely than developed countries to be influenced by local information. Harvey (1995b) examines the sensitivity of the emerging market returns to measures of global economic risk. He found that emerging markets have little or no sensitivity, which confirms the results of previous studies. He concludes that the world-market model fails to explain the emerging market returns.

Bekaert (1995) develops a return-based measure of market integration for nineteen emerging equity markets. He then investigates the relation between that measure, other return characteristics, and broadly defined investment barriers. Two conclusions emerge from the analysis. First, global factors account for a small fraction of the variation in expected returns in most markets, and global predictability has declined over time. Second, emerging markets exhibit differing degrees of market integration with the U. S. market, and the differences are not necessarily associated with direct barriers to investment.

Tesar and Warner (1995) find no evidence of relation between the volume of US transaction in foreign equity and local turnover rates or volatility of stock returns. This finding implies that the activity of US investors is not the source of excess volatility or high turnover on local (emerging) equity markets.

\section{Objectives of the Research}

The objectives of the research are the following:

- To investigate whether the companies with larger size of market lot are more stable than that of smaller market lot size.

- To analyze if the companies with higher face value are more stable than that of lower face value.

- To find out whether the companies with higher $\mathrm{P} / \mathrm{E}$ ratio are more unstable than that of lower $\mathrm{P} / \mathrm{E}$ ratio, and last but not least

- To investigate the relationship between net assets value (NAV) of companies with the volatility of stock returns.

\section{Methodology}

To investigate the issues of return and stock market volatility, this study uses daily all share price index of Dhaka Stock Exchange for the period of 2000-2009. This research is unique in the sense that it has considered very extensive and long time-series data set. Day to day price index data from January 2000 through December 2009 have been taken into account. In this study 92 DSE enlisted companies have been considered. For covering all the industries of DES, companies are selected randomly. In this study Net Asset Value (NAV) per share, Price Earnings (P/E) ratios, face values and market lot sizes are considered as independent variables and the standard deviation has been considered as the measurement of market volatility and is considered as the dependant variable. Considering these a regression analysis has been conducted for this study. 
Among the independent variables, Net Asset Value (NAV) of each company for 10 years has been taken into consideration and finally average NAV of each company is calculated for the analysis. Price Earnings (P/E) Ratio of each company for 10 years has been considered and their averages are calculated. Both the face values as well as market lot size of the company are fixed. In case of market lot size it varies from company to company that's why a dummy variable has been created. The companies for which market lot size fall in 1 to 10 are assumed as1, for 11 to 50 it is taken as 2, and above 50 is considered as 3 for regression analysis.

Returns are calculated as follows:-

$$
R_{i t}=\frac{P_{i t}-P_{i t-1}}{P_{i t-1}}
$$

Where $\mathrm{R}_{\mathrm{it}}$ is the return at time $\mathrm{t}, \mathrm{Pt}$ and $\mathrm{P}_{\mathrm{t}-1}$ are the closing price at time $t$ and $t-1$, respectively for its stock.

The average day-to-day changes over a certain period (say, one year) is measured by adding together all changes for a given period $(n)$ and calculated average $\left(R_{m}\right)$ as follows:

$$
R_{m}=\frac{\sum R_{t}}{n}
$$

\section{Risk}

Risk is defined as the standard deviation around the expected return. In effect, we equated a security's risk with the variability of its return. More dispersion or variability about a security's expected return meant the security was riskier than one with less dispersion.

\section{Standard Deviation}

Standard deviation is a statistical term that measures the amount of variability or dispersion around the average. So standard deviation works as a measure of volatility. Square root of mean squared deviation of the values from mean is called the standard deviation. The following formula is used to calculate the standard deviation of the returns.

$$
\sigma=\sqrt{\frac{\sum\left(x-x^{-}\right)^{2}}{n}}
$$

The function to be considered is

$$
\sigma=\mathrm{f} \text { (Market lot size, Face value of the share, P/E Ratio, NAV Per share) }
$$

Specifically, the regression equation becomes:

$$
\sigma=\alpha+\beta_{1} x_{1}+\beta_{2} x_{2}+\beta_{3} x_{3}+\beta_{4} d_{1}+\beta_{5} d_{2}+e
$$

Where,

$$
\begin{gathered}
\sigma=\text { Volatility (Mean Standard deviation) } \\
\alpha=\text { Intercepts } \\
\left.d_{1}=\begin{array}{l}
1,1 \tau \text { market lot size is } 1-10 . \\
0, \text { Otherwise }
\end{array}\right\} \\
d_{2}=\left\{\begin{array}{l}
1,1 \tau \text { market lot size is } 11-50 . \\
0, \text { Otherwise }
\end{array}\right\} \\
x_{1}=\text { face value } \\
x_{2}=\text { Average } \mathrm{P} / \mathrm{E} \\
x_{3}=\text { Average NAV } \\
\mathrm{e}=\text { Error term }
\end{gathered}
$$

Therefore, the hypothesis to be tested is,

$$
H_{0}: \beta_{1}=\beta_{2}=\beta_{3}=\beta_{4}=\beta_{5}=0
$$

\section{Empirical Results of the Study Descriptive Analysis}

The face value and their respective frequencies are stated in table-1. Among the sample only 1 company has face value Tk. 1. There are 17 companies with face value Tk. 10 and the rest of the companies i.e., 74 companies have face value Tk. 100. A total of 92 sample companies have been selected randomly for the present study.

Table 1. Face Value of the sample.

\begin{tabular}{ll}
\hline Face Value & Frequency \\
\hline 1 & 1 \\
10 & 17 \\
100 & 74 \\
Total & 92 \\
\hline
\end{tabular}

Source: www.dsebd.org

Table 2. Frequency table for market lot size.

\begin{tabular}{lll}
\hline Market lot size & Frequency & Percent \\
\hline $1-10$ & 38 & 41.3 \\
$11-50$ & 44 & 47.8 \\
51 or more & 10 & 10.9 \\
Total & 92 & $100 \%$ \\
\hline
\end{tabular}

The lot size refers to the number of shares that must be bought or sold together. For market lot sizes dummy variables have been created. Table- 2 shows the number of companies falling between 1-10, 11-50, and 51 or more. There are 38 companies with market lot size 1-10 has been selected indicating approximately $41 \%$ companies. A total of 44 companies have been selected with market lot size 11-50, indicating about $48 \%$ of the total sample. The rest of the companies are in market lot size of 51 or more which is about $11 \%$ of the total sample.

Table 3. Correlation between $N A V$ and $P / E$ ratio.

\begin{tabular}{ll}
\hline & Average P/E \\
\hline Average NAV & -0.16580687 \\
\hline
\end{tabular}


This table shows weak negative correlation between the average Price Earning $(\mathrm{P} / \mathrm{E})$ ratio and average Net Asset Value (NAV) per share. This is not surprising as it is expected that companies with higher NAV should have lower $\mathrm{P} / \mathrm{E}$ ratio and vice versa.

\section{Regression Analysis}

Tables 4, 5, and 6 show the regression results of the model. The above findings indicate that volatility is positively correlated with face value, market lot size, $\mathrm{P} / \mathrm{E}$ ratio and NAV per share which is very poor statistically. The regression model indicates significant relationship between the independent and the dependent variables, but only NAV per share has the significant impact on the market volatility. However, considering the explanatory power of the model only $3.6 \%$ of the variation in volatility is explained by the independent variables considered under this model.
Table 4. Model Summary.

\begin{tabular}{lllll}
\hline Model & R & R Square & $\begin{array}{l}\text { Adjusted R } \\
\text { Square }\end{array}$ & $\begin{array}{l}\text { Std. Error of the } \\
\text { Estimate }\end{array}$ \\
\hline 1 & $.189^{\mathrm{a}}$ & .036 & .029 & $1.15762642392 \mathrm{E} 1$ \\
\hline
\end{tabular}

a. Predictors: (Constant), Net Asset Value Per Share, P/E Ratio, Market Lot Size, Face Value

Table 5. Analysis of Variance.

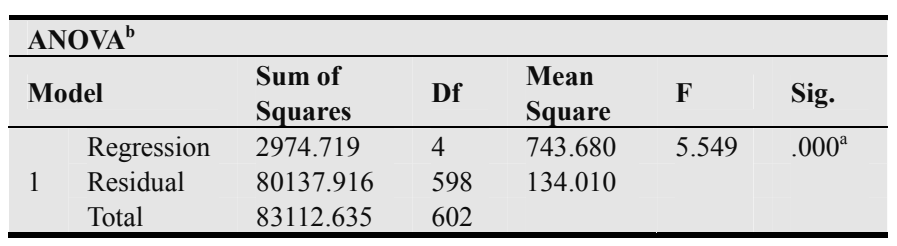

a. Predictors: (Constant), Net Asset Value Per Share, P/E Ratio, Market Lot Size, Face Value

b. Dependent Variable: Standard Deviation

Table 6. Regression Coefficients.

\begin{tabular}{|c|c|c|c|c|c|c|}
\hline \multirow{2}{*}{\multicolumn{2}{|c|}{ Model }} & \multicolumn{2}{|c|}{ Un standardized Coefficients } & \multirow{2}{*}{$\begin{array}{l}\text { Standardized Coefficients } \\
\text { Beta }\end{array}$} & \multirow{2}{*}{$\mathbf{t}$} & \multirow{2}{*}{ Sig. } \\
\hline & & B & Std. Error & & & \\
\hline \multirow{5}{*}{1} & (Constant) & -.647 & .764 & & -.847 & .397 \\
\hline & Face Value & .000 & .004 & .003 & .077 & .938 \\
\hline & Market Lot Size & .001 & .002 & .014 & .331 & .741 \\
\hline & P/E Ratio & -.004 & .013 & -.012 & -.293 & .770 \\
\hline & Net Asset Value Per Share & .004 & .001 & .189 & 4.556 & .000 \\
\hline
\end{tabular}

a. Dependent Variable: Standard Deviation (market volatility)

\section{Conclusion and Recommendation}

The significant regression analysis implies that irrelevant market information generally reflected in the stock price change in Bangladesh. As expected, we found no significant impact of face value and the market lot size in determining the volatility. Therefore, the recent unusual price hike of various companies prior to the changes in the face value and the market lot size should not have any basis the only relevant variable, however explaining the volatility of stock returns is the NAV per share. Despite its significance, the regression equation is very weak in explain the market volatility of the share prices.

Volatility in stock prices is a common phenomenon in the stock market. Individual stock price undergoes ups and downs which is a regular feature of an efficient stock market. In the absence of price volatility, potential investors lose interest to participate in the stock market. However, careful monitoring of volatility by the concerned authority is needed in DSE which is yet to achieve maturity as far as market volatility is concerned.

Dhaka Stock Exchange is an emerging market; there should be effective intervention when the market experiences excess volatility. During unpredictable movements of individual stock prices, it would be useful for the authority to identify the factors behind such price movements and quickly disseminate the information to interested stakeholders. In addition, the authority may take measures to make available all relevant information relating to real worth of the companies experiencing excess volatility in stock prices, especially to the investors. It is also important to ensure adequate supply of stocks through active participation of the government in the capital market particularly to dampen the excess demand. The regulatory authority of DSE should take necessary steps for sustainable development of the market.

Beside the independent variables, the model could have included flowing of new information and by the process that incorporates new information into market prices. While it could also consider the factors relating with a number of economic factors, such as financial leverage, corporate bond yields, corporate earnings and dividend yields, company takeover or merger, insider trading, stock trading activity, volatility of interest rates, bond prices, and other macroeconomic variables are other factors that need to be considered while investigating on this topic. For further study on the subject matter other technical, fundamental and other factors may be used to predict the stock market volatility in Dhaka Stock Exchange. This task is left to the further research on the topic.

\section{Reference}

[1] Aggarwal, R., Inclan, C., and Leal, R, (1999), "Volatility in Emerging Stock Markets", Journal of Financial and Quantitative Analysis, Vol. 34, 33-55.

[2] Aggarwal, R. and P. Rivoli, (1990), "Fads in the Initial Public Offering Market?" Financial Management, 19, 45-57.

[3] Batra, A, (2004), "Stock Return Volatility Persistence in India: 1973-2003", Working Paper, ICRIER, New Delhi, India. 
[4] Baillie, R. and Degennaro, R, (1990), "Stock Return and Volatility", Journal of Financial and Quantitative Analysis, Vol. 25, 203-214.

[5] Barua, S. and M. H. Rahman (2006), "Monetary Policy and Capital Market Development in Bangladesh", Bangladesh Bank Quarterly, Vol. IV, No. 2.

[6] Bekaert, G., Harvey, C. and Lundblad, C. (2005), Did financial liberalization spur economic growth? Journal of Financial Economics 77, 3-55.

[7] Bessler, D. A., and J. Yang (2003), "The structure of interdependence in international stock markets", Journal of International Money and Finance 22, 261-287.

[8] Bollerslev, T., (1986), "Generalized Autoregressive Conditional Heteroskedasticity", Journal of Econometrics, Vol. 72, 307-327.

[9] Bollerslev, T., Chou, R. Y., and Kroner, K. F., (1992), "ARCH Modeling in Finance: A Review of the Theory and Empirical Evidence", Journal of Econometrics, Vol. 52, 5-59.

[10] Brandt, M. W. and Kang, Q., (2003) "On the Relationship between the Conditional Mean and Volatility of Stock Returns: A latent VAR Approach", Working Paper, University of Pennsylvania.

[11] Chowdhury, A. R. (1994), "Statistical Properties of Daily Return from the Dhaka Stock Exchange", Bangladesh Development Studies, Vol. XXII, No. 4

[12] Claessens, S., Dasgupta, S., and Glen, J., (1993) "Stock Price Behaviour in Emerging Stock Market," in Stijin Claessens and Sudarshan Gooptu, (eds.), Portfolio Investment in Developing Countries, World Bank Discussions Paper, 228, Washington, D. C.

[13] Campbell, J. Y., Lo, A. W., and Mackinlay, A. C., (1997), The Econometrics of Financial Markets, Princeton.

[14] Chou, R. Y., (1998), "Volatility Persistence and Stock Valuations: Some Empirical Evidence using GARCH", Journal of Applied Econometrics, Vol. 3, 279-294.

[15] Choudhury, T., (1994), "Stock Markets Volatility and the crash of 1987: Evidence from Six Emerging. Markets", Journal of International Money and Finance, Vol. 1.5, 969981.

[16] Cohen K., Ness, W., Okuda, H., Schwartz, R., and Whitcomb, D., (1976), "The Determinants of Common Stock Returns Volatility: An international Comparison," Journal of Finance, Vol. 31, 733-740

[17] Edwards, F. (1998), "Does Futures Trading Increase Stock Market Volatility?" Financial Analysts Journal, January/February 1998.

[18] Engle, R. F., (1982), "Autoregressive Conditional Heteroskedasticity with Estimates of UK Inflation", Econometrics, Vol. 50, 987-1008.

[19] Engle, R. F., and Bollerslev, T., (1986), "Modeling the Persistence of Conditional Variances", Econometric Reviews, Vol. 5, 81-87.
[20] Ferson, W., and Harvey, C. (1993), "The risk and predictability of international equity returns," Review of Financial Studies 6, 527-566.

[21] French, K. R, Schwert, W. G., and Stambugh, R. F., (1987), "Expected Stock Return and Volatility", Journal of Financial Economics, Vol. 19, 3-29.

[22] Habib, M. A. and Ljungqvist, A. P. (2001) Underpricing and entrepreneurial wealth losses in IPOs, Review of Financial Studies 14, 433-458.

[23] Glosten, L. R., Jagannathan, R., and Runkle, D. E., (1993), "On the Relation between the Expected Value and Volatility of the Nominal Excess Returns on Stocks", The Journal of Finance, Vol. 48, 1779-1801.

[24] Haque, M., and Hassan, M. K., "Stability, Predictability and Volatility of Latin American Emerging Markets", University of Orleans, Working Paper, 2000.

[25] Harvey, C. R., "Portfolio Enhancement using Emerging Markets and Conditioning Information", in Stijn Classens and Shan Gooptu, Eds., Portfolio Investment in Developing Countries (Washington: The World Bank Discussion Series, 1993, 110-144.

[26] Harvey, C. R., "The Cross-section of Volatility and Autocorrelation in Emerging Markets", Finanzmarkt und portfolio Management, Vol. 9, 1995a, 12-34.

[27] Harvey, C. R., "Predictable Risk and Return in Emerging Markets", The Review of Financial Studies, Vol. 8, 1995b, 773-816.

[28] Harvey, C. R., "The Specification pf Conditional Expectations", Journal of Empirical Finance, Vol. 8(5), 2001, 573-637.

[29] Imam, A. O. and A. S. M. M. Amin (2003), "Volatility in the Stock Return: Evidence from Dhaka Stock Exchange", Journal of Institute of Bankers Bangladesh, Vol. 51, No. 1.

[30] Jain, R. K. (2001), Putting Volatility to Work, ACTIVE TRADERS, April 2001.

[31] Kanniainen, J. (2007), "On Dividend Expectations and Stock Return Volatility", International Research Journal of Finance and Economics, Issue 12.

[32] Karolyi, G. A. (2001), Why Stock Return Volatility Really Matters, Preliminary and incomplete version, February 2001.

[33] Khalily, M. A. Baqui. et. al. (2003), "Capital Market Development in Bangladesh: Need For More MacroEconomic and Financial Policy Interventions", Journal of Institute of Bankers Bangladesh, Vol. 50, No. 2.

[34] Li, K., (2002), "Long-memory versus Option-Implied Volatility Prediction", Journal of Derivatives, Vol. 9(3), 9-25.

[35] Mollah, A. S., Mobarek, A., (2007),. "Does Stock Market Volatility Differ Across Counties? Evidence from Fifty International Markets", Melbourne, Australia.

[36] Rahman, M. L. Nahar, N. and Mostafa, S. G. (2010a), "Holiday Effect on Stock Returns in Dhaka Stock Exchange (DSE)-an Empirical Investigation", Proceeding of the International Conference on Business Competencies in a Changing Global Environment 2010. Global Business Management Forum (GBMF), USA and Southeast University Bangladesh. 
[37] Rahman, M. L., Nurun, N. and Mollah, F. A. (2010b), "Dayof-the-Week Effect: Evidence from Dhaka Stock Exchange under Six-Days-a-Week trading." Proceedings of the International Conference on Knowledge Globalization 2010, ISBN: 978-984-33-1691-2, Suffolk University, USA, Knowledge Globalization Institute, USA and North South University Bangladesh.
[38] Schwert, G. W. and R. Stambaugh (1987), "Expected Stock Returns and Volatility", Journal of Financial Economics, No. 19.

[39] Shahiduzzaman, M. and M. S. Naser (2006), "Volatility in the Overnight Money-Market Rate in Bangladesh: Recent Experiences”, Bangladesh Bank Quarterly, Vol. IV, No. 2. 